\title{
Chapter 16 \\ Redesigning of Curriculum and Training \\ for Skills for Green Jobs in the Republic of Korea
}

Namchul Lee

\section{Introduction}

Green growth and conditions for a green economy are high on the agenda of the G20 and the United Nations conference on sustainable development in 2012. The Republic of Korea is the world's seventh largest emitter of carbon dioxide and is also more prone to climate change. The Republic of Korea is quite rightly praised for seeing and seizing the opportunity of a transition toward a green economy and delivering green growth early on and is already reaping a harvest in terms of a pathway toward sustainable development.

The Government of the Republic of Korea pronounced its National Strategy and 5-Year Plan for "Low-Carbon Green Growth" in 2008. The Republic of Korea aims to become one of the top seven green growth nations by 2020 and one of the top five by 2050. Based on the nation's vision for the Republic of Korea's green growth, the Korean government has focused on upgrading the skills of existing manpower in green industries and encouraged this new manpower development to lead green industries. Under this government policy, industries, universities, research institutes, and the government have been reorganizing green job skill development programs and training courses with the aim of creating suitably skilled manpower in the green job sector.

This chapter is the case study commissioned by Korea Eximbank and analyzed the approaches taken by the Republic of Korea's TVET institutions to gear skills training curriculum and courses toward the needs of green jobs. ${ }^{1}$ The Republic of

\footnotetext{
${ }^{1}$ This chapter revised and complemented the contents of Lee and others (2012), Education and Skills for Inclusive Growth and Green Jobs: The Republic of Korea's Experiences on Education and Skills for Green Jobs. This project was carried out and commissioned by the Export-Import Bank of Korea in 2011.

N. Lee $(\bowtie)$

Korea Research Institute for Vocational Education and Training (KRIVET),

Seoul, Republic of Korea

e-mail: nclee@krivet.re.kr
} 
Korea's Green Growth Deal outlines extensive commitments toward shifting the economy toward green growth. The Republic of Korea was the country that allocated the largest proportion of its fiscal stimulus package (in the aftermath of the fiscal crisis) toward green public initiatives. This chapter analyzes the steps taken in the country to prepare training programs and developing skills aligned to such an overarching green economy vision and the lessons they offer to developing countries.

The chapter proceeds as follows: The next section explains Green Growth National Strategy and Green New Deal Strategy in the Republic of Korea. The third section discusses job skill development and green jobs. The fourth section explores change of vocational education and training under the green growth policy. The fifth section analyzes cases of redesigning curriculum and training in TVET institution, and the final section presents conclusions.

\section{Green Growth National Strategy and Green New Deal Strategy}

\section{Green Growth National Strategy}

\section{Background of Promoting Green Growth}

The Republic of Korea set low-carbon green growth as a new paradigm of national development in 2008, and based on this, the Republic of Korea started to push forward with green growth in earnest by launching the Presidential Committee on Green Growth under the direct guidance of the President in 2009. This section discusses the processes through which the Republic of Korea has been seeking green growth by analyzing the background of the presentation of low-carbon green growth as a new paradigm of national development and presenting governmental policies for green growth.

The Republic of Korea depends on imports for $97 \%$ of its energy and its energy consumption has been gradually increasing. In addition, as the Republic of Korea has an industry structure with a high proportion of manufacturing, a heavy energyconsuming industry, it has faced a situation where new and renewable energy and green energy have become necessary rather than an option. So far, the Republic of Korea has achieved tremendous growth through fostering major industries such as heavy chemical and electronics. However, as it has entered a low-growth phase, it has been necessary to set green growth as its new growth engine. The Republic of Korea's GDP has stalled between 11th and 13th for the past 15 years since it was recorded as the world's 12th biggest in 1993.

\section{Republic of Korea's Vision and Strategies of Green Growth}

The Republic of Korea has implemented three detailed strategies and 10 policy directions to be among the top seven green growth power nations by 2020 and among the top five by 2050 . Three strategies are adapted to the climate change and 
energy independence, creating new growth engines, improving quality of life, and enhancing the nation's status. Ten policy directions based on this are the efficient greenhouse gas reduction, the enhancement of de-petroleum and energy self-reliance, the enhancement of climate adaptation capability, the development of green technology and a future growth engine through the development of green technology, making an industry green and fostering the green industry, the sophistication of the industry structure, the establishment of bases for green economy, the formation of green land transportation, the green revolution of lives, and the realization of the world's renowned green growth model nation. To establish and execute the national strategies that include the policy goals, propulsion strategies, and major tasks for low-carbon green growth of the nation, the Republic of Korea enacted the Low-Carbon Green Growth Basic Act in 2009 and has pushed forward with various policies based on this Act.

The Republic of Korea established the Presidential Committee on Green Growth (PCGG) in February 2009 under the direct supervision of the President to facilitate the realization of the new national vision of "low-carbon green growth." The Committee consists of 47 members, including relevant government ministers and representatives from key national research institutes, and has the mandate to discuss all subjects related to green growth, including the planning and implementation of policies on green growth as well as the coordination of government activities in this area.

Through the Committee, the Republic of Korea announced 27 national strategies for Green IT in May 2009, finalized the Five-Year Action Plan for Green Growth in July 2009, confirmed the voluntary reduction of its GHG emissions to $30 \%$ below business-as-usual (BAU) levels by 2020 in November 2009, and announced the enforcement of the "Framework Act on Low Carbon, Green Growth" in April 2010.

The establishment of the PCGG is one of the most distinctive features of the Republic of Korea's green growth strategy. The launching of the Committee is proof of the government's dedication to promoting this new development paradigm, and the body's effective leadership thus far has been the most critical element in developing effective green growth strategies and policies. Thus, the prioritization of green growth as its top national agenda has allowed the Republic of Korea to become one of the early green leaders. Furthermore, the Republic of Korea believes that green growth can be turned from vision into reality with the help of relevant ministries, advisory groups, and private sector actors.

In particular, the PCGG's focus on strengthening internal networks between central and local governments and heeding public opinion has created an open structure under which effective green growth policies have been developed. On July 6,2009 , the Republic of Korea announced the objective of becoming the world's seventh largest green economic power by 2020 and the fifth largest by 2050 . To achieve these goals, the Republic of Korea has formulated three strategies for green growth: (1) mitigating climate change and promoting energy independence, (2) creating new engines for economic growth, and (3) improving the quality of life and enhancing the Republic of Korea's international standing. These strategies are designed for facilitating the implementation of various sub-policies established under the "low-carbon green growth" vision, and the 10 key policy directions deemed necessary to achieve the vision (see Table 16.1). 
Table 16.1 Vision and strategies of the Republic of Korea's green growth

\begin{tabular}{|c|c|}
\hline National strategies & Policy directions \\
\hline $\begin{array}{l}\text { 1. Mitigating climate change and promoting } \\
\text { energy independence }\end{array}$ & $\begin{array}{l}\text { 1. Effective mitigation of greenhouse gas } \\
\text { emission } \\
\text { 2. Reduction of the use of fossil fuels and the } \\
\text { enhancement of energy independence } \\
\text { 3. Strengthening the capacity to adapt to climate } \\
\text { change }\end{array}$ \\
\hline 2. Creating new engines of economic growth & $\begin{array}{l}\text { 4. Development of green technologies } \\
\text { 5. The "greening" of existing industries and the } \\
\text { promotion of green industries } \\
\text { 6. Advancement of the industrial structure } \\
\text { 7. Engineering a structure basis for a green } \\
\text { economy }\end{array}$ \\
\hline $\begin{array}{l}\text { 3. Improving the quality of life and enhancing } \\
\text { the Republic of Korea's international } \\
\text { standing }\end{array}$ & $\begin{array}{l}\text { 8. Greening the land and water and building a } \\
\text { green transportation infrastructure } \\
\text { 9. Bringing a green revolution to daily life } \\
\text { 10. Becoming a role model for the international } \\
\text { community as a green leader }\end{array}$ \\
\hline
\end{tabular}

Source: Presidential Committee on Green Growth (2010)

The policies set out under the first Five-Year Action Plan (2009-2013) for green growth have been well received by the country's society, resulting in a substantial increase in public and private investment (PCGG 2010). ${ }^{2}$

This proactive plan and investment strategies demonstrate the strong will of the Government of the Republic of Korea in promoting green growth policies and are symbolic of its efforts to secure required financial resources. According to the PCGG (2010), the budget mentioned above is to be spent specifically on various activities associated with the research and development of green technologies, including those related to solar energy and fuel cells, the restoration of the four major rivers, and the development of green transportation.

The government enacted and promulgated the "Framework Act on Low Carbon, Green Growth" on January 13, 2010, which went into effect on April 14, 2010. The main purpose of the Framework Act is to implement legal measures that can effectively address climate change and energy issues and to promote sustainable development. Meanwhile, the Act also mandates the establishment of institutional and implementation systems, for instance, the Presidential Committee on Green Growth, for low-carbon green growth strategies so that the policies could be carried out in an efficient and systematic.

A technological transformation that reduces the carbon intensity of industry, in particular in the Republic of Korea's manufacturing sector, is therefore a core component of a green growth strategy. The Republic of Korea's Green Growth

\footnotetext{
${ }^{2}$ Under the Five-Year Action Plan, KRW 107 trillion (approximately $\$ 83.6$ billion USD), which represents $2 \%$ of the Republic of Korea's GDP, is to be allocated for managing issues related to climate change and energy, sustainable transportation, and the development of green technologies between 2009 and 2013.
} 
Table 16.2 List of 27 core technologies in the Republic of Korea's Green Growth National Plan

\begin{tabular}{|c|c|c|}
\hline Sector & 27 Core technologies & Notes \\
\hline \multirow[t]{2}{*}{ Climate change } & 1. Monitoring and modeling for climate change & (4) \\
\hline & 2. Climate change assessment and adaptation & (4) \\
\hline \multirow[t]{8}{*}{ Energy source technology } & 3. Silicon-based solar cells & (1) \\
\hline & 4. Non-silicon-based solar cells & (4) \\
\hline & 5. Bioenergy & (4) \\
\hline & 6. Light water reactor & (1) \\
\hline & 7. Next-generation fast reactor & (3) \\
\hline & 8. Nuclear fusion energy & (3) \\
\hline & 9. Hydrogen energy R\&D & (3) \\
\hline & 10. High-efficiency fuel cell & (3) \\
\hline \multirow{10}{*}{$\begin{array}{l}\text { Efficiency improvement } \\
\text { technologies }\end{array}$} & 11. Plant-growth-promoting technology & (3) \\
\hline & 12. Integrated gasification combined cycle & (3) \\
\hline & 13. Green car & (2) \\
\hline & $\begin{array}{l}\text { 14. Intelligent infrastructure for transportation and } \\
\text { logistics }\end{array}$ & (4) \\
\hline & 15. Green city and urban renaissance & (3) \\
\hline & 16. Green building & (3) \\
\hline & 17. Green process technology & (2) \\
\hline & 18. High-efficiency light-emitting diodes/green IT & (1) \\
\hline & 19. IT-combined electric machines & (3) \\
\hline & 20. Secondary batteries & (2) \\
\hline \multirow[t]{6}{*}{ End-of-pipe technology } & 21. $\mathrm{CO}_{2}$ capture, storage, and processing & (3) \\
\hline & 22. Non- $\mathrm{CO}_{2}$ processing & (2) \\
\hline & 23. Assessment of water quality and management & (2) \\
\hline & 24. Alternative water resources & (2) \\
\hline & 25. Waste recycling & (2) \\
\hline & $\begin{array}{l}\text { 26. } \mathrm{R} \& \mathrm{D} \text { in monitoring and processing for hazardous } \\
\text { substances }\end{array}$ & (3) \\
\hline $\mathrm{R} \& \mathrm{D}$ in virtual reality & 27. Virtual reality & $(2)$ \\
\hline
\end{tabular}

Source: UNEP (2008)

Notes:

(1) Technologies for short-term intensive investment;

(2) Technologies for midterm intensive investment;

(3) Technologies for long-term intensive investment;

(4) Technologies for long-term gradual investment; and KRW (Korean won; US 1 dollar - 1,136 won, on 24 January 2012)

Plan seeks to promote the development of 27 core green technologies that would provide future engines of growth to the economy (See Table 16.2).

Table 16.3 shows that the fiscal expenditure on green growth from 2009 to 2013. Annual average rate of mitigating climate change and promoting energy independence is the highest among three categories.

Table 16.4 shows the development stage plan through the Republic of Korea's green growth in 2010, in 2013, in 2020, and in 2030. Confirming green growth infrastructure plan (2010) included preparing growth infrastructure through promoting green growth national project. Green technology and industrial power country plan (2013) include creating green jobs, and seven leading green growth 
Table 16.3 Fiscal expenditure on green growth (2009-2013) (Unit: trillion KRW, percent)

\begin{tabular}{|c|c|c|c|c|c|}
\hline Category & Total & 2009 & 2010-2011 & 2012-2013 & $\begin{array}{l}\text { Annual } \\
\text { average } \\
\text { rate }\end{array}$ \\
\hline Total & 107.4 & 17.5 & 47.3 & 41.6 & 10.2 \\
\hline $\begin{array}{l}\text { Mitigating climate change and promoting } \\
\text { energy independence }\end{array}$ & 56.9 & 8.6 & 29.2 & 19.2 & 14.0 \\
\hline Creating new engines of economic growth & 28.6 & 4.8 & 10.7 & 13.1 & 9.4 \\
\hline $\begin{array}{l}\text { Improving the quality of life and enhancing the } \\
\text { Republic of Korea's international standing }\end{array}$ & 27.9 & 5.2 & 10.5 & 12.2 & 3.6 \\
\hline
\end{tabular}

Source: Presidential Committee on Green Growth (2010)

Table 16.4 Development stage plan through the Republic of Korea's green growth

\begin{tabular}{|c|c|c|}
\hline Year & Development plan & Contents \\
\hline 2010 & $\begin{array}{l}\text { Confirming green growth } \\
\text { infrastructure }\end{array}$ & $\begin{array}{l}\text { Preparing growth infrastructure through promoting } \\
\text { green growth national project }\end{array}$ \\
\hline 2013 & $\begin{array}{l}\text { Green technology and industrial } \\
\text { power country }\end{array}$ & $\begin{array}{l}\text { Green technology, increase industrial export } \\
\text { Green job creation } \\
\text { Securing new growth engine through green growth }\end{array}$ \\
\hline 2020 & $\begin{array}{l}\text { Seven leading green growth } \\
\text { country }\end{array}$ & $\begin{array}{l}\text { Achieving world seven leading green growth country } \\
\text { Supporting green growth to East Asia's underdeveloped } \\
\text { country } \\
\text { Enhancing green growth national image }\end{array}$ \\
\hline 2030 & $\begin{array}{l}\text { World's top five green growth } \\
\text { country }\end{array}$ & $\begin{array}{l}\text { Achieving green developed country in the field of } \\
\text { economic, social, and so on }\end{array}$ \\
\hline
\end{tabular}

Source: Presidential Committee on Green Growth (2010)

country plan (2020) has a goal achieving world's seven leading green growth county, and world's top five green growth plan (2030) includes achieving green developed country in the field of economic, social, and so on.

\section{Green New Deal Strategy}

\section{Purpose and Scope}

The Green New Deal Project has been formulated by developing it into policies that can bring concrete performances such as job creation as well as potential growth engines by promoting Green and New Deal at the same time. Green New Deal aims to maximize the policy effects by systematically integrating duplicated green projects with unclear goals by converging green growth strategies such as lowcarbon, eco-friendliness, and resource saving with job creation policies and also aims to lead the green economy realization and the preservation of the Earth's environment. To this end, the roles are efficiently divided so that such policies are actually operated and executed. 


\begin{tabular}{|c|c|c|c|c|}
\hline & $\begin{array}{l}\text { Forest } \\
\text { Biomass } \\
\cdot \text { Resource } \\
\text { Recycling }\end{array}$ & $\begin{array}{l}\text { Cn New Deal P } \\
\text { Creating Gre } \\
\text { Green Home }\end{array}$ & $\begin{array}{l}\text { ject> } \\
\text { Living Space } \\
\text { Green Office }\end{array}$ & \\
\hline & $\begin{array}{l}\cdot 4 \text { Rivers } \\
\cdot \text { Railroad }\end{array}$ & \begin{tabular}{|l}
-Green \\
Technology \\
.Green \\
IT/SW
\end{tabular} & \begin{tabular}{|l}
-Renewable \\
Energy \\
-Water \\
Environment \\
-LED \\
Application \\
\end{tabular} & \\
\hline \multirow{2}{*}{\multicolumn{2}{|c|}{$\begin{array}{l}\text { Great-sphere Economic Area } \\
\text { Development } \\
\text {-Expansion on supporting company } \\
\text { infrastructure } \\
\text { - Road · Port } \text { Logistics } \\
\text { <The Republic of Korea } \\
\text { New Deal Project> }\end{array}$}} & SW & \multirow{2}{*}{\multicolumn{2}{|c|}{$\begin{array}{l}\cdot \text { Hi-Tech Convergence } \\
\text { Industry } \\
\text {-Medical Education } \\
\text { Finance Service Industry } \\
\text { Culture Contents } \\
\text { Tourism Industry } \\
\text { <New Growth Engine } \\
\text { Project> }\end{array}$}} \\
\hline & & & & \\
\hline
\end{tabular}

Fig. 16.1 Scope of Green New Deal Projects (Source: State Council of Ministry of Strategy and Finance, Ministry of Education, Science and Technology, Ministry of Culture, Sports and Tourism, Ministry of Food, Agriculture, Forestry and Fisheries, Ministry of Knowledge Economy, Ministry of Environment, Ministry of Land, Transport and Maritime Affairs, Prime Minister's Office, National Emergency Management Agency, Korea Forest Service 2009)

The Green Growth Committee and Planning Group set policy directions and strategies and evaluate them, and the Ministry of Planning and Finance adjusts finances and operates the support system that adjusts duplicate projects among departments and sets priorities among related projects. In addition, each department takes charge of exploring Green New Deal projects and executing the selected projects. The inclusive scope of Green New Deal has selected the following as its major projects to promote the transition to a green economy and create growth and jobs at the same time (refer to Fig. 16.1).

\section{Promotion Strategies}

Figure 16.2 explains that promotion goals and strategies of Green New Deal Project in the Republic of Korea.

\section{Expansion of Resources Reuse}

The Green New Deal Project has the following nine core goals:

1. Reviving the four major rivers and the rearrangement of their surroundings 


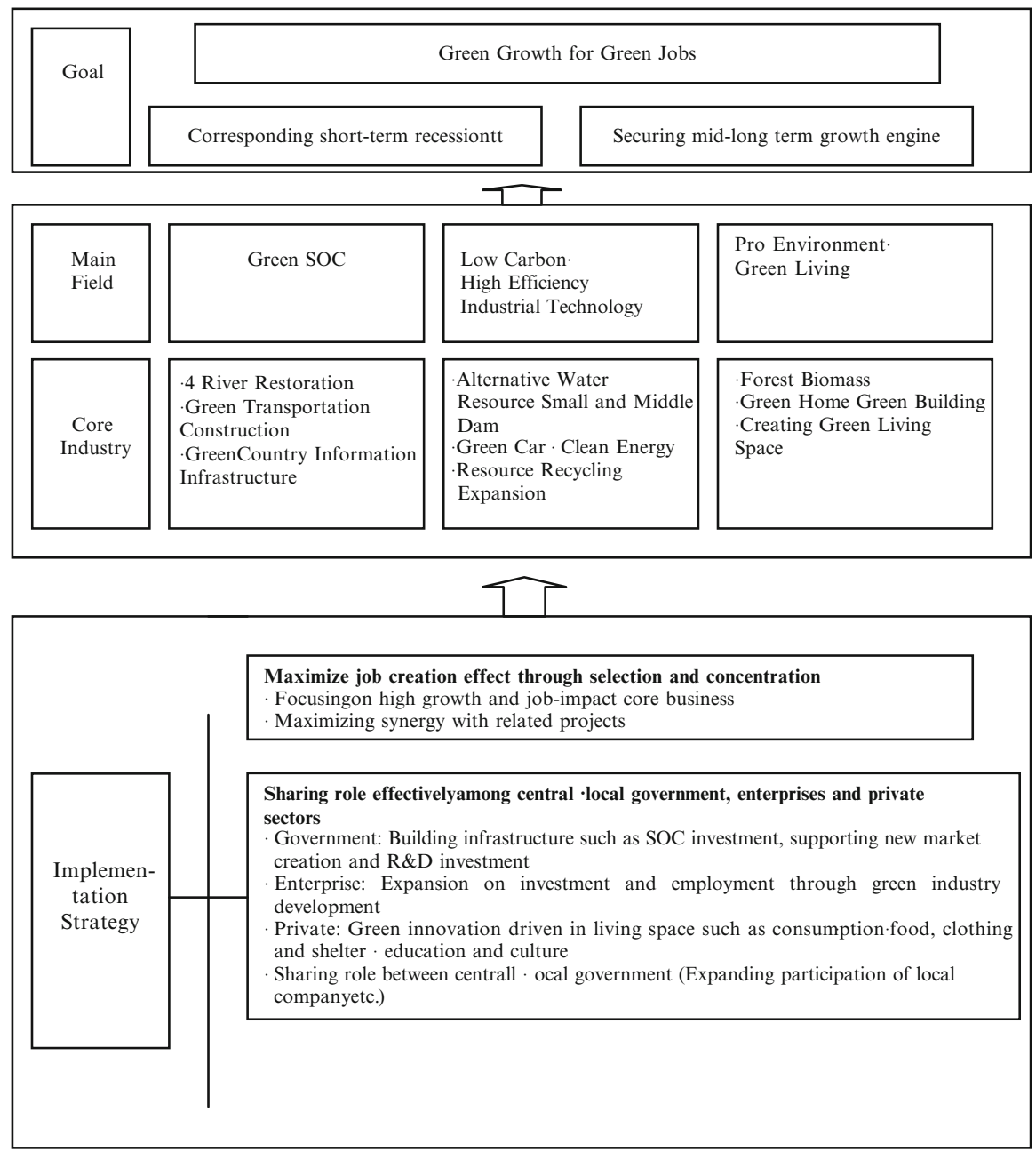

Fig. 16.2 Promotion goals and strategies of Green New Deal Project (Source: State Council of Ministry of Strategy and Finance, Ministry of Education, Science and Technology, Ministry of Culture, Sports and Tourism, Ministry of Food, Agriculture, Forestry and Fisheries, Ministry of Knowledge Economy, Ministry of Environment, Ministry of Land, Transport and Maritime Affairs, Prime Minister's Office, National Emergency Management Agency, Korea Forest Service 2009)

\section{Green transportation network establishment}

3. Establishment of green national information infrastructure

4. Securing alternative water resources and building eco-friendly small- and medium-sized dams

5. Distribution of green cars and clean energy

6. Expansion of resources reuse 
7. Activation of forest biomass use

8. Expansion of energy-saving green homes, offices, and schools

9. Forming pleasant green life space

Table 16.5 represents finance requirements and size of job creation from the core projects. Finance includes national treasury and local private burden. Through the propulsion of a total of 36 projects ( 9 core projects and 27 related projects), a total of KRW 50 trillion is invested for years 2009-2012, creating a total of 960,000 jobs. In the case of the 9 core projects, a total of KRW 39 trillion is invested, creating 690,000 jobs, while the 27 related projects will create 270,000 jobs with the investment totaling to KRW 11 trillion during the same period. For years 2009-2012, the number of jobs which would be created for youth (aged 15-29) has been estimated to a total of 100,000 centered on reviving the four major rivers and the forest biomass project.

\section{Job Skill Development and Green Jobs}

Green skills mean the ability required to execute green jobs and to produce new green products necessary for jobs relating to manufacturing, services, and marketing. In the context of green growth, because the intended policy aspects are also emphasizing that traditional jobs can be incorporated into the green industry, green skills also include abilities for finding out and understanding and learning and innovating low-carbon technologies in addition to technical ability.

A green job means that it is related to agricultural, manufacturing, research and development, administration organizations, and service activities that contribute to protect or restore the quality of the environment. In particular, it refers to jobs related to economic behavior for reducing energy, material, and water consumption and reducing carbon emission through very efficient strategies. Green jobs can be classified by required technologies or skills. Therefore, with the advent of the green economy, the job market is affected by the following three aspects. First, the green economy increases the jobs in relation to it by increasing the employment demand for the existing jobs related to the green economy. Second, the green economy changes tasks, skills, and knowledge required for existing jobs. Third, the green economy creates new jobs.

Such changes have created jobs in three ways. First of all, it is the creation of an increase in demand for green occupations. This means that the impact of green economy activities and technologies increases the demand of existing occupations. However, such impacts do not accompany meaningful change for the requirements of the work and workers of the occupation. That is, although the work context may change, tasks themselves do not.

Second, it creates green enhanced skill occupations. In this job type, the impact of green economy activities and technologies causes meaningful changes to the work of existing jobs and the requirements of the workers. This impact may or may 
Table 16.5 Finance requirements and size of job creation form core projects

\begin{tabular}{|c|c|c|c|c|c|c|c|}
\hline \multirow[b]{2}{*}{ Project } & & \multicolumn{3}{|c|}{$\underline{\text { Finance (100 million won) }}$} & \multicolumn{3}{|c|}{$\underline{\text { Job creation (person) }}$} \\
\hline & & $\begin{array}{l}\text { Before } \\
(2009)\end{array}$ & $\begin{array}{l}\text { Additional } \\
\text { amount } \\
(\sim 2012) \\
\end{array}$ & Total & $\begin{array}{l}\text { Before } \\
(2009)\end{array}$ & $\begin{array}{l}\text { Additional } \\
\text { amount } \\
(\sim 2012) \\
\end{array}$ & Total \\
\hline Total & & 43,626 & 456,866 & 500,492 & 93,360 & 863,060 & 956,420 \\
\hline \multirow{9}{*}{$\begin{array}{l}\text { Core Business } \\
\text { (9) }\end{array}$} & 4 River restoration & 4,881 & 139,895 & 144,776 & 7,000 & 192,960 & 199,960 \\
\hline & $\begin{array}{l}\text { Green transportation } \\
\text { expansion }\end{array}$ & 18,349 & 78,187 & 96,536 & 25,042 & 113,025 & 138,067 \\
\hline & $\begin{array}{l}\text { Building national } \\
\quad \text { space } \\
\text { information } \\
\text { integration } \\
\text { system }\end{array}$ & 250 & 3,467 & 3,717 & 816 & 2,304 & 3,120 \\
\hline & $\begin{array}{l}\text { Rainwater outflow } \\
\text { facilities, small- } \\
\text { and medium- } \\
\text { sized dam }\end{array}$ & 1,845 & 7,577 & 9,422 & 3,063 & 13,069 & 16,132 \\
\hline & $\begin{array}{l}\text { Green car and clean } \\
\text { energy } \\
\text { distribution }\end{array}$ & 3,209 & 17,318 & 20,527 & 1,643 & 12,705 & 14,348 \\
\hline & Waste recycling & 506 & 8,794 & 9,300 & 2,377 & 13,819 & 16,196 \\
\hline & $\begin{array}{l}\text { Green forest } \\
\text { gardening }\end{array}$ & 3,131 & 21,043 & 24,174 & 22,498 & 148,204 & 170,702 \\
\hline & $\begin{array}{l}\text { Green home, green } \\
\text { school project }\end{array}$ & - & 80,500 & 80,500 & - & 133,630 & 133,630 \\
\hline & $\begin{array}{l}\text { Eco-river } \\
\quad \text { composition }\end{array}$ & 52 & 4,786 & 4,838 & 393 & 10,396 & 10,789 \\
\hline \multirow[t]{8}{*}{$\begin{array}{l}\text { Business link } \\
\text { (27) }\end{array}$} & $\begin{array}{l}\text { Maintenance } \\
\text { business on } \\
\text { disaster risk } \\
\text { district }\end{array}$ & 5,137 & 19,901 & 25,038 & 8,529 & 33,038 & 41,567 \\
\hline & $\begin{array}{l}\text { Clean Korea practice } \\
\text { business }\end{array}$ & 437 & 1,666 & 2,103 & 3,236 & 11,310 & 14,546 \\
\hline & $\begin{array}{l}\text { Greening riparian } \\
\text { areas }\end{array}$ & 331 & 7,669 & 8,000 & 827 & 19,073 & 19,900 \\
\hline & $\begin{array}{l}\text { Building transfer } \\
\text { facilities }\end{array}$ & 1,782 & 3,396 & 5,178 & 2,959 & 5,639 & 8,598 \\
\hline & $\begin{array}{l}\text { Building main } \\
\text { express bus } \\
\text { system }\end{array}$ & 200 & 1,544 & 1,744 & 253 & 1,955 & 2,208 \\
\hline & $\begin{array}{l}\text { National bicycle } \\
\text { route network }\end{array}$ & - & 4,980 & 4,980 & - & 8,268 & 8,268 \\
\hline & $\begin{array}{l}\text { Road bike express } \\
\text { pilot project }\end{array}$ & - & 3,000 & 3,000 & - & 4,980 & 4,980 \\
\hline & $\begin{array}{l}\text { Building energy } \\
\text { integrated } \\
\text { management } \\
\text { system }\end{array}$ & - & 340 & 340 & - & 760 & 760 \\
\hline
\end{tabular}


Table 16.5 (continued)

\begin{tabular}{|c|c|c|c|c|c|c|c|}
\hline \multirow[b]{2}{*}{ Project } & & \multicolumn{3}{|c|}{ Finance (100 million won) } & \multicolumn{3}{|c|}{ Job creation (person) } \\
\hline & & $\begin{array}{l}\text { Before } \\
(2009)\end{array}$ & $\begin{array}{l}\text { Additional } \\
\text { amount } \\
(\sim 2012) \\
\end{array}$ & Total & $\begin{array}{l}\text { Before } \\
(2009)\end{array}$ & $\begin{array}{l}\text { Additional } \\
\text { amount } \\
(\sim 2012) \\
\end{array}$ & Total \\
\hline & $\begin{array}{l}\text { Promoting the usage } \\
\text { of electronic } \\
\text { documents }\end{array}$ & & 800 & 800 & - & 8,430 & 8,430 \\
\hline & $\begin{array}{l}\text { Road-based } \\
\text { underground } \\
\text { facilities } \\
\text { computerization }\end{array}$ & 400 & 2,199 & 2,599 & - & 7,767 & 7,767 \\
\hline & $\begin{array}{l}\text { Entering overseas } \\
\text { water industry }\end{array}$ & 199 & 1,790 & 1,989 & 171 & 1,281 & 1,452 \\
\hline & $\begin{array}{l}\text { Seawater } \\
\text { desalination } \\
\text { technology } \\
\text { development }\end{array}$ & 246 & 878 & 1,124 & 1,700 & 5,700 & 7,400 \\
\hline & Wastewater reuse & 403 & 3,364 & 3,767 & 431 & 5,570 & 6,001 \\
\hline & $\begin{array}{l}\text { Securing originality } \\
\text { in car technology }\end{array}$ & 414 & 1,522 & 1,936 & 42 & 154 & 196 \\
\hline & $\begin{array}{c}\text { Bioethanol vehicle } \\
\text { dissemination }\end{array}$ & - & 30 & 30 & - & 60 & 60 \\
\hline & $\begin{array}{l}\text { Bioethanol (E5) } \\
\text { demonstration } \\
\text { distribution }\end{array}$ & - & 272 & 272 & - & 575 & 575 \\
\hline & $\begin{array}{l}\text { Biomass energy } \\
\text { recovery }\end{array}$ & 362 & 10,858 & 11,220 & 2,853 & 21,519 & 24,372 \\
\hline & $\begin{array}{l}\text { Building biomass } \\
\text { production } \\
\text { infrastructure }\end{array}$ & 546 & 2,262 & 2,808 & 582 & 4,3432 & 4,924 \\
\hline & $\begin{array}{c}\text { Closed landfill site } \\
\text { redevelopment }\end{array}$ & - & 5,300 & 5,300 & - & 9,230 & 9,230 \\
\hline & $\begin{array}{l}\text { Disaster prevention, } \\
\text { damaged forest } \\
\text { restoration } \\
\text { (forest biomass } \\
\text { utilization) }\end{array}$ & 786 & 6,541 & 7,327 & 8,430 & 44,218 & 52,648 \\
\hline & $\begin{array}{l}\text { Forest biomass } \\
\text { utilization }\end{array}$ & 65 & 816 & 881 & 420 & 2,710 & 3,130 \\
\hline & $\begin{array}{l}\text { Building rural theme } \\
\text { park }\end{array}$ & 95 & 755 & 850 & 95 & 755 & 850 \\
\hline & $\begin{array}{l}\text { LED lighting } \\
\text { replacement } \\
\text { project in public } \\
\text { facilities }\end{array}$ & - & 13,356 & 13,356 & - & 10,030 & 10,030 \\
\hline
\end{tabular}


Table 16.5 (continued)

\begin{tabular}{|c|c|c|c|c|c|c|c|}
\hline \multirow[b]{2}{*}{ Project } & & \multicolumn{3}{|c|}{ Finance (100 million won) } & \multicolumn{3}{|c|}{ Job creation (person) } \\
\hline & & $\begin{array}{l}\text { Before } \\
(2009)\end{array}$ & $\begin{array}{l}\text { Additional } \\
\text { amount } \\
(\sim 2012)\end{array}$ & Total & $\begin{array}{l}\text { Before } \\
(2009)\end{array}$ & $\begin{array}{l}\text { Additional } \\
\text { amount } \\
(\sim 2012)\end{array}$ & Total \\
\hline & $\begin{array}{l}\text { Building green IT } \\
\text { technology test } \\
\text { bed }\end{array}$ & - & 100 & 100 & - & 10,000 & $\overline{10,000}$ \\
\hline & $\begin{array}{l}\text { Training green home } \\
\text { doctor }\end{array}$ & & 160 & 160 & - & 1,332 & 1,332 \\
\hline & $\begin{array}{l}\text { The roof of the } \\
\text { building, wall } \\
\text { afforestation } \\
\text { business }\end{array}$ & - & 1,130 & 1,130 & - & 2,800 & 2,800 \\
\hline & Building eco-road & - & 310 & 310 & - & 920 & 920 \\
\hline & $\begin{array}{l}\text { Reconstructing the } \\
\text { small-scale idle } \\
\text { facilities into } \\
\text { culture facilities }\end{array}$ & - & 360 & 360 & & 532 & 532 \\
\hline
\end{tabular}

Source: Report of the State Council of Ministry of Strategy and Finance, Ministry of Education, Science and Technology, Ministry of Culture, Sports and Tourism, Ministry of Food, Agriculture, Forestry and Fisheries, Ministry of Knowledge Economy, Ministry of Environment, Ministry of Land, Transport and Maritime Affairs, Prime Minister's Office, National Emergency Management Agency, Korea Forest Service (2009)

not increase the employment demand for jobs. While the essential purpose of the job is the same, external factors such as its work, skills, knowledge, and qualifications change.

According to a joint study by UNEP, ILP, IOE and ITUC, a green job is defined as "the job that contributes to preserving and recovering the quality of environment by performing its role of reducing the environment force in companies and various economic areas ultimately to the sustainable level of society." Such green jobs can be found in all industry areas including agriculture, manufacturing, and service (see Table 16.6).

Recently, there have been many debates about whether which green jobs are decent jobs. Optimists suggest that "green jobs are providing fair wages, good extra salaries, promotion opportunities, and working conditions beneficial to health." Pessimists suggest that many green jobs are unstable, expose workers to physical risks, and pay less than the recommended minimum wage. This debate is leading the policy direction of green job creation. That is, creating decent, environmentally friendly jobs is the policy objective.

Over the next 5 years, the growth rate of green jobs $(6.0 \%)$ is expected to be much higher than the average growth rate of the total jobs $(1.3 \%)$ in the Republic of Korea (green growth committee, 4 November 2009). New jobs will be created by, in particular, renewable energy and environmental improvement programs. In 2006 , the total number of employees in environmental industries was 390,406, of which 178,174 employees $(45.6 \%)$ were directly related to environmental fields. 
Table 16.6 Green jobs by sector

\begin{tabular}{|c|c|}
\hline Sector & Types of green jobs \\
\hline Energy supply & Coal gasification, cogeneration, renewable energy, fuel cells \\
\hline Transportation & $\begin{array}{l}\text { Fuel-efficient vehicles, hybrid electric and fuel cell vehicle, non-power } \\
\text { transportation (bicycle, walking), change in land use and residence pattern } \\
\text { (less dependence on vehicle) }\end{array}$ \\
\hline Manufacturing & Pollution control, energy and material efficiency, clean manufacturing \\
\hline Construction & $\begin{array}{l}\text { Fuel-efficient bulb, electric and office equipment, solar energy system, } \\
\text { environmentally friendly building, solar house, zero-emission house }\end{array}$ \\
\hline Recycling & Recycling, extended producer responsibility, durable and recyclable products \\
\hline Agriculture & $\begin{array}{l}\text { Soil conservation, efficient water use, organic farming, better access to market } \\
\text { from farm }\end{array}$ \\
\hline Forestry & $\begin{array}{l}\text { Reforestation, subordinate forestry, sustainable forest management and } \\
\text { accreditation, logging ban }\end{array}$ \\
\hline
\end{tabular}

Source: UNEP (2008)

By 2012, about 8,000 social jobs in environment will be created, and 35,000 jobs will be created in wind and solar energy.

While the employment induction coefficient per billion KWN of environment industry is 10.3 and 18.8 in wind energy, the employment induction coefficient of solar energy (102.0) and social jobs (119.0) is much higher than other fields. Solar energy has the potential to create a larger number of new jobs than conventional industries, offering a solution to the problem of "jobless growth." By 2012, 100,000 new jobs in renewable energy, another 100,000 in energy efficiency, and 17,000 in waste-to-resources sectors will be created. The renewable energy industry alone is expected to have generated 950,000 new jobs by 2030 .

Between 2009 and 2013, the number of green jobs will continually increase by $9.0 \%$ (annual average increase rate, 33,628 jobs). The total number of green jobs in 2013 is estimated to be 482,090 jobs. Green jobs in agriculture, fishing, and mining industries will increase by $3.4 \%$, while green jobs in manufacturing and services will increase by $4.5 \%$ and $12.1 \%$ respectively (Table 16.7 ).

The following Table 16.8 shows the number of green jobs by skill level. Between 2009 and 2013, the number of green jobs will continually increase by $6.1 \%$ (annual average increase rate), by $11.0 \%$, and by $9.3 \%$, in basic level, middle level, and advanced level, respectively. The total number of green jobs in 2013 is estimated to be 482,091 jobs.

\section{Change of Vocational Education and Training Under the Green Growth Policy}

To understand the institutional framework of the Republic of Korea's vocational education and training, it is necessary to understand how vocational education and training is operated in the Republic of Korea. Vocational education in the Republic 
Table 16.7 Green jobs prospects by industry (Unit: person, percent)

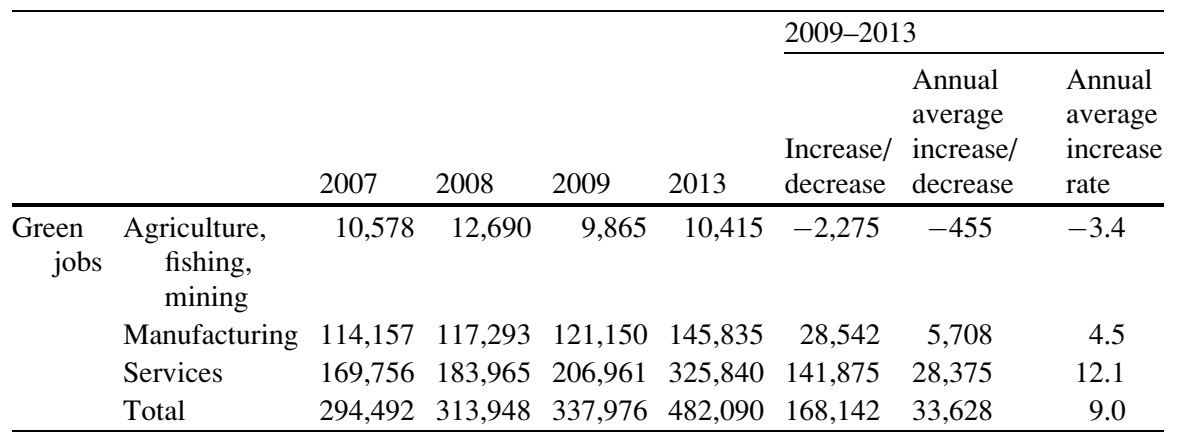

Source: Interministerial Committee, Unpublished report (2009)

Table 16.8 Green jobs prospects by skill level (Unit: person, percent)

\begin{tabular}{|c|c|c|c|c|c|c|c|c|}
\hline & & & & & & 2009-201 & & \\
\hline & & 2007 & 2008 & 2009 & 2013 & $\begin{array}{l}\text { Increase/ } \\
\text { decrease }\end{array}$ & $\begin{array}{l}\text { Annual } \\
\text { average } \\
\text { increase/ } \\
\text { decrease }\end{array}$ & $\begin{array}{l}\text { Annual } \\
\text { average } \\
\text { increase } \\
\text { rate }\end{array}$ \\
\hline Green & Basic & 53,992 & 56,265 & 57,570 & 75,662 & 19,398 & 3,880 & 6.1 \\
\hline jobs & Middle & 35,569 & 38,037 & 43,242 & 64,037 & 26,000 & 5,200 & 11.0 \\
\hline & Advanced & 204,931 & 219,647 & 237,163 & 342,392 & 122,745 & 24,549 & 9.3 \\
\hline & Total & 294,492 & 313,949 & 337,975 & 482,091 & 168,143 & 33,629 & 9.0 \\
\hline
\end{tabular}

Source: Inter-ministerial Committee, Unpublished Report (2009)

Notes:

Basic level: ISCED 3A, high school graduates, craftsmen

Middle level: ISCED 5B, 2- or 3-year college graduates, technicians, industrial engineers

Advanced level: ISCED 5A, 4-year university graduates, managers, researchers, engineers, professional engineers

ISCED International Standard Classification of Education

of Korea generally refers to the education provided at the stage of middle or high school education to foster personnel under para-technician or paraprofessional. However, practically, it refers to the formal education received in specialized high schools at the stage of middle education and in specialized colleges at the stage of higher education within the direction (regulations) of the Ministry of Education, Science, and Technology.

The education organizations with the purpose of providing vocational education include specialized high schools under "the Act of Elementary and Secondary Education," technology high schools (exceptional organizations), specialized colleges and technology colleges under "the Act of Higher Education," in-house universities under "the Continuing Education Act," and continuing vocational education institutes under "the Act of the Establishment, Operation of Private Institutions, and Private Tutoring." Technical colleges and in-house universities 
have unique characteristics in that the subject of establishment and operation is the company itself.

Vocational training in the Republic of Korea includes improvement training and reemployment training for those who are already in the labor market or who are unemployed, as well as initial training provided to help them enter the labor market for the first time. However, reeducation of professionals is not included in the category of vocational training. As such, the importance put on improvement training and reemployment training means that vocational training policies are closely linked with labor market policies. Practically, vocational training can be regarded as learning in which employment insurance is reimbursed from vocational training organizations within the scope of direction (regulations) of the Ministry of Labor, or learning that is supported by the budget of the government.

Vocational training organizations are public occupational training organizations operated by the government. They include occupational ability development and training facilities, occupational ability development training companies, occupational ability development groups as well as Korea Polytechnics. They also include schools under the "Higher Education Act," continuing education centers under the "Continuing Education Act," private institutes under the "Act on the Establishment, Operation of Private Institutes, and Private Tutoring," and training facilities made by owners or owner groups of a company for employees, etc. According to the Act on Industrial Education Promotion and Industry-Academic Cooperation Promotion, education to teach necessary knowledge, technologies, and attitude needed for all kinds of industries can be regarded as vocational education and all of those organizations that provide such vocational education can be regarded as vocational education organizations. Therefore, general high schools and 4-year universities can also be considered organizations that provide occupational education.

\section{Cases of Redesigning Curriculum and Training in TVET of the Republic of Korea}

In the labor market, there will be a discrepancy between manpower with traditional proficiency and green experienced manpower newly required by the industry society. Such ripple effects on the labor market show the positive and negative effects of green job growth. Existing jobs will disappear as many new jobs are created because non-regular workers increase as regular workers increase. Although it is believed that green jobs are related to future technology, all jobs are also noteworthy. The net size of newly created jobs within technological development and new industries is not as big as expected. It indicates that it is more important to facilitate green growth through education and training for technology and skill transfer of existing manpower by changing jobs in existing industries to fit the green environment. 
In this respect, the Government of the Republic of Korea has tried to transform the technology and skill of existing manpower to fit the green industries in tandem with green growth and developed new personnel that will lead the green industry. This section focuses on the discussion of the strategies and changes in vocational education and training for developing green talents who would support the green growth of the Republic of Korea. However, as the industrialization of the Republic of Korea's economy was developed under the backdrop of nation-led economic development policies and national human resources development policies, the characteristics of the Republic of Korea's vocational education and training are first introduced to provide basic understanding on such attributes. This is because it would be hard to understand the Republic of Korea's vocational training program newly established in accordance with the nation's green growth policies, if the human resources development policies, which greatly helped the Republic of Korea's unprecedented fast economic development, are not taken into consideration.

The green job vocational education and training development expansion policy tasks for the green job, set by the Green Growth Committee, are presented. The government tries enhancing technologies, technical manpower training to promote the green industry as the new growth engine. To foster technology functional manpower to promote the green industry as the new growth engine, the government enhances the training of high-quality technological manpower and technical manpower of core green industries, where demand has been on the increase with the industrialization of core green technologies. It designates or creates manpower training centers and pushes forward raising technical manpower through cooperation with sectoral councils in the green industry area.

In addition, as a project is underway to reorganize unemployment training as green friendly so that those leaving non-green industry can swiftly move to green employment, it heightens the possibility of those unemployed people in traditional manufacturing sectors transferring to green-related industry areas. Also, the government enhances to reorganization status of technology, technical manpower vocational education, and training development. Among the political tasks presented on the government's manpower training plan, "the expansion of ability development" is mainly dealt with by the Ministry of Employment and Labor, which can be summarized as the reorganization of Korea Polytechnic, ${ }^{3}$ public occupational training organizations (2-year multifunction course), or the expansion of green job training of the national infrastructure strategy job training supported by the government for civil occupational training organization. About $30 \%$ of the national infrastructure strategy industry job training is expected to be used for

\footnotetext{
${ }^{3}$ Korea Polytechnic, which has been taking care of vocational public training in the Republic of Korea, presents a paradigm in education that is future-oriented, dynamic, and innovative. Korea Polytechnic represents the Republic of Korea's prosperous future of an advanced technology. For an efficient college administration and education, Korea Polytechnic runs I-VII colleges with 4 specialized ones, which are in total 11 colleges and 24 campuses all around the country. There are 2-year degree courses, 6 months and 1 year of technician courses, and 500 different education and training programs.
} 
green job training. Going forward, green job training will be executed in the form of project financing as the government encourages companies and related associations to actively participate in the program. Namely, if the training organization constitutes the training curriculum and organizes manpower, facilities, equipment, and training cost on its own and applies for it, the government reviews the program and supports it later. Other than these, the manpower movement, through the retraining of the existing employees, is executed in the form of retraining in the technician courses at Korea Polytechnics.

\section{Korea Polytechnics Reorganization Case ${ }^{4}$}

\section{Corporate Body's Level}

Korea Polytechnics have reorganized departments based on existing traditional foundation industry into ones related to the green industry areas earnestly since 2009 , trying to raise mid-level technology manpower needed for the commercialization phase of the green industry. Specifically, through the department reorganization projects, Korea Polytechnics fostered mid-level technicians in areas of new and renewable energy, carbon reduction energy, LED applications, and the green transportation sector.

Directions of this reorganization plan are, first, to establish a mid-level technician fostering system, which will be necessary at the commercialization phase of green industries. Therefore, manpower fostering sectors and size shall be set based on the manpower supply and demand trend in the Republic of Korea's green industry sector and technology manpower level. Second, the plans aim to expand the vocational training courses in the green industry for young unemployed people with higher education.

Based on such objectives, Korea Polytechnics plan to raise the number of mid-level technical staff through the department reorganization for the 7 years from 2009 through 2015. The departments are being reorganized through public vocational training institutions by each college through collaborations with the regions and industries where Korea Polytechnics are located in the green industry sectors set as of 2009. At public vocational training institutions, the education and training course development, curriculum specialization, teacher operation plan (securing status of related field specialized teachers and instructors from academic-industry cooperation), investment in facilities and equipments, and planned use of them linked with the regional industry base and green technologies are all evaluated for selection (see Table 16.9).

In terms of the selection process, the corporation forms an evaluation committee constituting internal and external specialists and selects through document screening from the submitted applications in the 1st phase and finally selects the reorganized departments through the 2nd phase, oral announcements. In 2010, nine campuses were reorganized to include departments in new and renewable

\footnotetext{
${ }^{4}$ This section revised and complemented the contents of Ko (2010).
} 
Table 16.9 2010 Green technology department reorganization status

\begin{tabular}{|c|c|c|c|}
\hline Sector & Campus & Major & Note \\
\hline \multirow[t]{5}{*}{ Renewable energy } & Jeju & Electric Control & $\begin{array}{l}\text { Certified technician } \\
\text { course }\end{array}$ \\
\hline & Iksan & Electric Control & $\begin{array}{l}\text { Certified technician } \\
\text { course }\end{array}$ \\
\hline & Pohang & Electric Control & $\begin{array}{l}\text { Certified technician } \\
\text { course }\end{array}$ \\
\hline & Hongsung & Electrical Measurement Control & $\begin{array}{l}\text { Two-year diploma } \\
\text { course }\end{array}$ \\
\hline & Gwangji & Electrical Measurement Control & $\begin{array}{l}\text { Two-year diploma } \\
\text { course }\end{array}$ \\
\hline Highly water treatment & Daejeon & Industrial Facility Automation & $\begin{array}{l}\text { Two-year diploma } \\
\text { course }\end{array}$ \\
\hline \multirow[t]{3}{*}{$\begin{array}{l}\text { Green transportation } \\
\text { system }\end{array}$} & Pusan & Automobile & $\begin{array}{l}\text { Two-year diploma } \\
\text { course }\end{array}$ \\
\hline & Gangneung & Industrial Diver & $\begin{array}{l}\text { Two-year diploma } \\
\text { course }\end{array}$ \\
\hline & Mokpo & $\begin{array}{l}\text { Shipbuilding Electric Control } \\
\text { (30) }\end{array}$ & $\begin{array}{l}\text { Two-year diploma } \\
\text { course }\end{array}$ \\
\hline
\end{tabular}

energy, sophisticated water treatment, and green transportation system. In 2012, 8 more departments are scheduled to be reorganized (see Table 16.10).

Table 16.11 shows Korea Polytechnic University's curricular restructuring plans from 2009 to 2013.

Once selected as a reorganized department through an open process, the reorganized department goes through the following curriculums development process (refer to Fig. 16.3). It organizes the curricula after analyzing the tasks through on-site inspection of companies in the industry, prepares for the facilities and equipment supply and demand plans, goes through review and feedback of industrial specialists, and completes a final checkup of curricula, facilities, and equipment before finalizing all the programs of curricula, facilities, and equipment to be bought for use.

\section{Department Reorganization Case of Chungju Campus, Korea Polytechnics IV}

The Chungju Campus of Korea Polytechnics IV (new and renewable energy) was selected as a green education organization that fosters green growth leaders by the Green Growth Committee along with its Changwon Campus (carbon dioxide reduction technology). The Green Growth Committee designated 48 green education organizations which will mainly perform its roles of expanding the pannational understanding on green growth policies and developing specialized capabilities in green growth. The Committee designated them with the aim of 
Table 16.10 Scheduled 2012 green technology department reorganization

\begin{tabular}{|c|c|c|c|}
\hline Sector & Campus & Major & Note \\
\hline \multirow[t]{3}{*}{ Renewable energy } & Cheongju & Electric Energy & $\begin{array}{l}\text { Two-year diploma } \\
\text { course }\end{array}$ \\
\hline & Daegu & Smart Electricity & $\begin{array}{l}\text { Two-year diploma } \\
\text { course }\end{array}$ \\
\hline & Changwon & Smart Electricity Electron & $\begin{array}{l}\text { Two-year diploma } \\
\text { course }\end{array}$ \\
\hline Low-carbon energy & Gwangreoung & $\begin{array}{c}\text { Air-Conditioning } \\
\text { Refrigerating }\end{array}$ & $\begin{array}{l}\text { Certified technician } \\
\text { course }\end{array}$ \\
\hline Highly water treatment & Iksan & Industrial Facility & $\begin{array}{l}\text { Certified technician } \\
\text { course }\end{array}$ \\
\hline \multirow[t]{2}{*}{ LED application } & Sungnam & Smart Electricity & $\begin{array}{l}\text { Two-year diploma } \\
\text { course }\end{array}$ \\
\hline & Nam Incheon & LED Applied Electricity & $\begin{array}{l}\text { Certified technician } \\
\text { course }\end{array}$ \\
\hline $\begin{array}{l}\text { Green transportation } \\
\text { system }\end{array}$ & $\begin{array}{l}\text { Seoul } \\
\text { Jeongsu }\end{array}$ & Automobile & $\begin{array}{l}\text { Two-year diploma } \\
\text { course }\end{array}$ \\
\hline
\end{tabular}

Table 16.11 Korea Polytechnic University's curricular restructuring plans (2009-2013) (Unit: numbers, 1,000,000 KWN)

\begin{tabular}{llrrrrrr}
\hline & & Total & 2009 & 2010 & 2011 & 2012 & 2013 \\
\hline Number of courses/department & Total & 65 & 13 & 13 & 13 & 13 & 13 \\
under restructuring & Technician & 50 & 10 & 10 & 10 & 10 & 10 \\
& Craftsman & 15 & 3 & 3 & 3 & 3 & 3 \\
Expected costs & Total & 65,500 & 13,100 & 13,100 & 13,100 & 13,100 & 13,100 \\
& Equipment & 59,800 & 11,960 & 11,960 & 11,960 & 11,960 & 11,960 \\
& Facilities & 5,700 & 5,700 & 5,700 & 5,700 & 5,700 & 5,700 \\
\hline
\end{tabular}

raising green growth leaders and specialists in the area by preparing programs that can systematically spread green growth policies and cultivate experience-oriented learning places.

Chungcheongbuk-do, where Chungju Campus is located, pushes forward with "Green Chungbuk," which includes regional green industry fostering, and prepares for a sustainable Chungbuk, concretizing the national-level green growth strategies at a regional level. Representatively, with the start of Cheongju, the solar valley establishment has been initiated to Cheongwon, Jeungpyung, Eumsung, Jincheon, Gweosan, and Chungju. In Chungcheongbuk-do, there are 21 companies in cell, module parts, and materials companies including Hyundai Heavy Industries, Korea Steel, Shinsung Holdings, Kyungdong Solar, and A-ONE TECH and 11 solar power equipment-related companies. With the location of many large companies investing in solar power industry, the largest production infrastructure of solar power parts in the Republic of Korea has been established. Furthermore, with Chungju International Airport, Chungcheongbuk-do is the most optimum place to act as a hub in Northeast Asia for advancement into the PRC's solar cell market and is also 


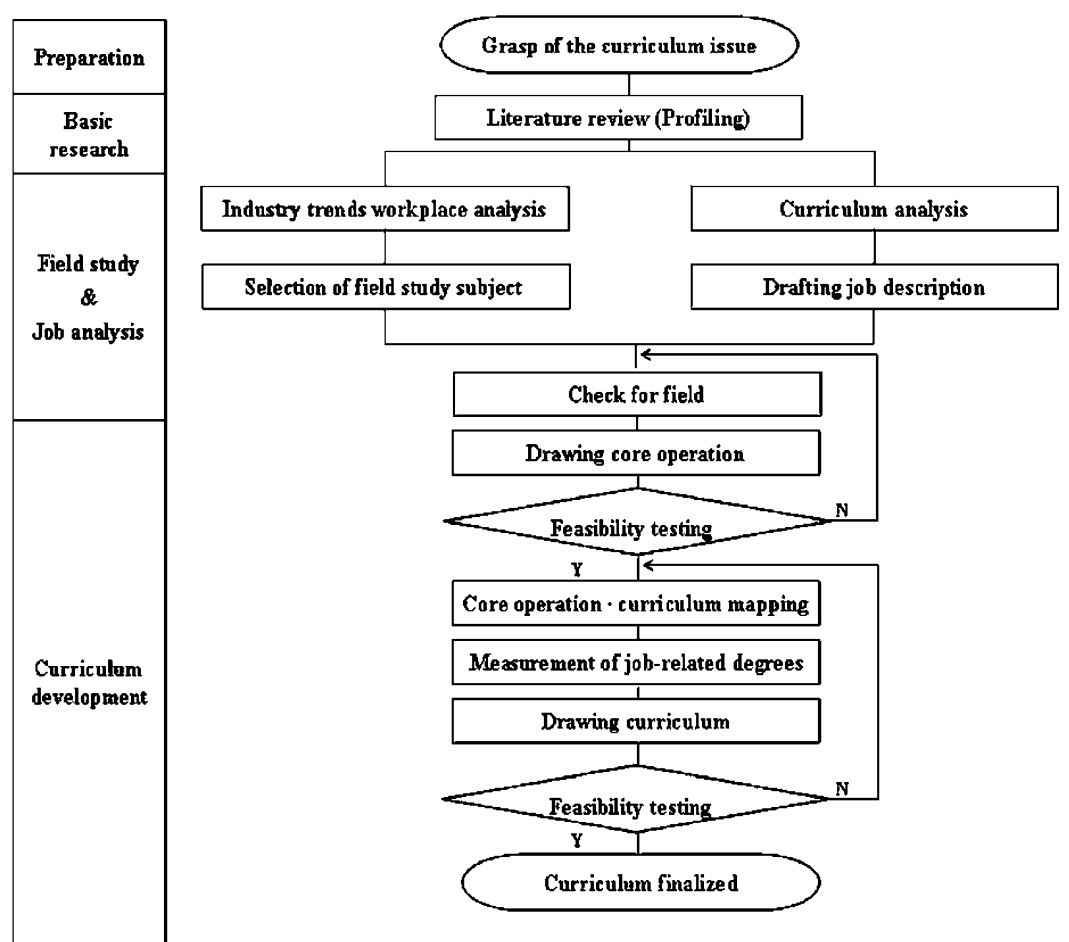

Fig. 16.3 Curriculum development process

equipped with optimum geological conditions for the fostering of solar power as the major growth engine of low-carbon green growth.

With the propulsion of green growth, a specialized industrial complex (on $990,000 \mathrm{~m}^{2}$ land) will be established in the 2nd Jeungpyung Industrial Complex in Chungbuk for the nationalization, $R \& D$, and certification support of related equipment and parts and materials to enhance global competitiveness of the solar power industry. KRW 65 billion will be invested from 2010 to 2013 to foster a comprehensive support organization related with the solar cell industry. The Solar Cell Comprehensive Technology Support Center promotes "Asia Solar Valley," a solar power industry cluster, by further fostering solar power parts and materials industries through the establishment of pilot line equipment facilities for nextgeneration cells, supporting tech-intensive companies with pilot scales, fostering manpower, and supporting academy-industry cooperative R\&D.

To attain this end, first, Chungcheongbuk-do plans to raise solar power specialists, along with the continued propulsion of 4 major strategic industryfostering measures of bioconductor, semiconductor, next-generation cells, electric-electronic fusion parts, etc., Second, Chungcheongbuk-do plans to execute six subprojects by inviting solar power companies, forming a specialized complex, fostering manpower, developing technologies, establishing the Solar Cell 
Comprehensive Technology Support Center, and designating a special solar district by investing a total of KRW 146.8 billion in the solar power industry from 2010 to 2014 and, of note, by investing KRW 10.0 billion for the promotion of its own projects. Third, Chungcheongbuk-do plans to nationalize the process equipment of production lines and support R\&D's process efficiency improvement as well as developing next-generation solar cell core technology (thin film type and dyesensitized solar cell) by co-establishing Chungbuk TP with Chungju University, Konkuk University, Chungbuk University, Cheongju University, and RIC together with residing companies.

Meanwhile, activities to entice companies have also been initiated with improving incentives tailored to solar companies necessary to establish the production cluster such as company concentration to establish solar power part and materials hub, inviting partner companies, and changing of business types of semiconductor companies. For those companies engaged in solar power businesses, the SME fostering fund and a special economy fund offer support. There is also a priority to revise related regulations such as fund support, technology development, and manpower fostering.

Fostering solar power personnel is the catalyst for the solar power generation. Therefore, Chungcheongbuk-do invested KRW 0.9 billion of regional funds to Chungbuk Semiconductor High School with the aim of securing company competitiveness by fostering specialists in solar power industry, producing solar power parts and materials, and operating related equipment, supporting the specialist raising project in general. In addition, Chungbuk created a solar cell department in a community college, supporting academy-industry R\&D-linked manpower exchange programs while creating graduate schools specializing in solar power and pushing forward with solar power research-centered university projects.

New and renewable energy have a lower economic value than existing fossil fuels and has many location restrictions depending on natural conditions such as wind and sunlight. Using its natural propensity for good sunlight, Chungcheongbuk-do set the solar power industry as its main energy source and currently research is being conducted with a view to providing the central region from Cheongju to Chungju with abundant solar power-related infrastructure and potentially designating it as a Specialized Solar Power Industry District to foster the industry.

Tailored to the regional strategies mentioned above, the Chungju Campus of Korea Polytechnics reorganized its electric measurement department to solar power in 2009. After the department was selected for reorganization through public vocational training institutions of the corporation, they made visits to nearby companies such as Techwin and Gyeongdong Solar Co., Ltd. to analyze tasks in solar power plant construction and solar cell module manufacturing sectors. It has led to the development of the following curricula (Table 16.12).

\section{Junior College Reorganization Case: Yeungjin College}

In 2010, Yeungjin College changed the existing electric department to the new and renewable energy category in order to raise human resources in the eco-friendly 
Table 16.12 Reorganized curriculums of electric measurement department of Korea Polytechnics, Chungju Campus

\begin{tabular}{|c|c|c|c|c|}
\hline \multirow[b]{2}{*}{ Classification } & \multirow[b]{2}{*}{ Subject } & \multirow{2}{*}{$\begin{array}{l}\text { Before } \\
\text { reorganization } \\
\begin{array}{l}\text { Completion of } \\
\text { hours }\end{array}\end{array}$} & \multirow{2}{*}{$\begin{array}{l}\begin{array}{l}\text { After } \\
\text { reorganization }\end{array} \\
\begin{array}{l}\text { Completion of } \\
\text { hours }\end{array}\end{array}$} & \multirow[b]{2}{*}{$\begin{array}{l}\text { Note (maintenance, } \\
\text { abolition, new, modified) }\end{array}$} \\
\hline & & & & \\
\hline \multirow[t]{3}{*}{ Liberal arts } & Computer & 60 & 60 & Maintenance \\
\hline & $\begin{array}{l}\text { Health and Ability } \\
\text { Development }\end{array}$ & 40 & 40 & Maintenance \\
\hline & $\begin{array}{l}\text { Occupation and } \\
\text { Society }\end{array}$ & 40 & 40 & Maintenance \\
\hline \multirow[t]{7}{*}{ Major theory } & Electric Theory & 60 & 50 & Modified \\
\hline & Electric Appliance & 40 & 20 & Modified \\
\hline & Automation Control & 40 & 30 & Modified \\
\hline & Power Electricity & 20 & 40 & Modified \\
\hline & Electric Facility & 40 & 20 & Modified \\
\hline & Solar PV Generation & 0 & 30 & New \\
\hline & $\begin{array}{l}\text { Solar Cell } \\
\text { Engineering }\end{array}$ & 0 & 30 & New \\
\hline \multirow{9}{*}{$\begin{array}{l}\text { Major } \\
\text { practice }\end{array}$} & Sequence Control & 220 & 160 & Modified \\
\hline & $\begin{array}{l}\text { Power Electric } \\
\text { Control }\end{array}$ & 100 & 100 & Maintenance \\
\hline & Electric CAD & 120 & 60 & Modified \\
\hline & PLC Control & 140 & 120 & Modified \\
\hline & Digital Control & 40 & 40 & Maintenance \\
\hline & Control Appliance & 140 & 80 & Modified \\
\hline & Electric Facility & 140 & 100 & Modified \\
\hline & Solar Cell Fabrication & 0 & 120 & New \\
\hline & Solar PV Generation & 0 & 100 & New \\
\hline $\begin{array}{l}\text { Project } \\
\text { practice }\end{array}$ & Project Practice & 80 & 80 & Maintenance \\
\hline OJT & OJT & 80 & 80 & Maintenance \\
\hline
\end{tabular}

energy sector, creating two new majors of new and renewable energy and digital electricity (quota of 280 students). Reflecting the fever for green growth, the competition rate for recruiting freshmen was 5.7:1, reflecting the great interest of students in this field. The college order-tailored education agreements with various companies, including representative companies such as LG Siltron; STX Solar Co., Ltd.; Mirinet Solar Co., Ltd.; LUXCO Co., Ltd.; and LS CNS.

The new and renewable energy major in the new and renewable energy category in Yeungjin College will foster specialists equipped with practical technologies such as solar cell process, power generation system, and power transformation technology (see Table 16.14). Order-tailored agreement classes related with this are currently being operated: 20 people for STX Solar Co., Ltd.; 20 for Mirinet Solar Co., Ltd.; 20 for KPE Co., Ltd.; 20 for LG Siltron; 10 for Gyeongwon Co., Ltd.; 10 for LUXCO Co., Ltd.; and 20 for Stetz Chippack Korea (LLC). 
The digital electric major will provide core personnel for the electric technology industry, which has been developing to become a high value-added cutting-edge industry as various digital technologies have been fused. This department aims to foster specialized technicians fully equipped with on-site practical capabilities in areas of electric control and power facilities design using computer technologies. The college currently operates various order-tailored education classes with various companies: 20 for LS CNS, Korea Power Construction Association, Korea Engineering Association, Korea Power Safety Association, etc. The courses in new and renewable energy, electricity section are operated as common classes of the 1st semester of freshman year and major classes are operated during the 2nd semester (Table 16.13).

Table 16.14 presents the main subject status on the department of renewable energy electricity in Yeungjin College.

Other than the above programs, Yeungjin College is currently operating shortterm education courses for employees supported by the Ministry of Employment and Labor (see Table 16.15). The education program is "Green Energy Power and Electricity Construction Practices," a ministry-supported project in which a consortium was formed with the Korea Power Construction Association and member companies, offering free education to improve the vocational ability of SME employees in the electric industry. In 2010, a total of 80 employees were educated during the 4-day reeducation sessions.

\section{Conclusions}

As the climate change policies are activated within the environment industry, and the green growth strategies are activated across all industries, demand for related personnel increases. In the meantime, as labor moves to the growth industry sectors, employment is expected to decrease in the waning industry sector. Furthermore, in the labor market, there will be a discrepancy between manpower with traditional proficiency and green experienced manpower newly required by the industry society. Such ripple effects on the labor market show the positive and negative effects of green job growth.

Although the effects of green jobs on the employment and labor market are mostly positive, we cannot neglect the other side of the employment effect. That is, existing jobs will disappear as many new jobs are created because non-regular workers increase as regular workers increase. Although it is believed that green jobs are related to future technology, all jobs are also noteworthy. The net size of newly created jobs within technological development and new industries is not as big as expected. It indicates that it is more important to facilitate green growth through education and training for technology and skill transfer of existing manpower by changing jobs in existing industries to fit the green environment.

In this respect, the Government of the Republic of Korea has tried to transform the technology and skill of existing manpower to fit the green industries in tandem 
Table 16.13 Curriculum department of renewable energy electricity in Yeungjin College

\begin{tabular}{|c|c|c|c|c|}
\hline & & \multicolumn{3}{|c|}{ Major in renewable energy } \\
\hline & & Freshman & Sophomore & Sophomore \\
\hline & & 2nd semester & 1st semester & 2nd semester \\
\hline \multirow[t]{2}{*}{$\begin{array}{l}\text { Freshman 1st } \\
\text { semester } \\
\text { (corequisite) }\end{array}$} & \multirow[t]{21}{*}{$\begin{array}{l}\text { Choose } \\
\text { major }\end{array}$} & Social Service & Social Service & $\begin{array}{l}\text { Vocational Ethics } \\
\text { and } \\
\text { Relationship }\end{array}$ \\
\hline & & $\begin{array}{l}\text { English } \\
\quad \text { Conversation }\end{array}$ & E-Learning Selection & $\begin{array}{l}\text { Visual } \\
\quad \text { Programming }\end{array}$ \\
\hline Social Service & & $\begin{array}{l}\text { E-Learning } \\
\text { Selection }\end{array}$ & Electric Installation & $\begin{array}{l}\text { LED Display } \\
\text { Lighting }\end{array}$ \\
\hline $\begin{array}{l}\text { E-Learning } \\
\text { Selection }\end{array}$ & & $\begin{array}{l}\text { Electric Apparatus } \\
\text { Practice }\end{array}$ & $\begin{array}{l}\text { Photovoltaic Power } \\
\text { Generation System }\end{array}$ & LED Display \\
\hline $\begin{array}{l}\text { Elementary } \\
\text { Mathematics }\end{array}$ & & Sequence Practice & $\begin{array}{l}\text { Inverter Electric Power } \\
\text { Modification }\end{array}$ & Applied Practice \\
\hline $\begin{array}{l}\text { Digital System } \\
\text { Practice }\end{array}$ & & & Practice & \\
\hline $\begin{array}{l}\text { Elementary } \\
\text { Experiment } \\
\text { Practice }\end{array}$ & & Solar Cell & $\begin{array}{l}\text { General Equipment } \\
\text { Maintenance }\end{array}$ & Monitoring System \\
\hline AutoCAD & & Renewable Energy & & OJT \\
\hline \multirow[t]{2}{*}{$\begin{array}{l}\text { Sensor Applied } \\
\text { Practice }\end{array}$} & & Applied Practice & $\begin{array}{l}\text { Electric Light Control } \\
\text { Practice }\end{array}$ & \\
\hline & & $\begin{array}{l}\text { Electronic Circuit } \\
\text { Practice }\end{array}$ & Practical English & \\
\hline C-Language & & \multicolumn{2}{|c|}{ Major in digital electricity } & \\
\hline Renewable & & Freshman & Sophomore & Sophomore \\
\hline $\begin{array}{l}\text { Energy Basic } \\
\text { Practice }\end{array}$ & & 2nd semester & 1st semester & 2nd semester \\
\hline Electric Circuit & & Social Service & Social Service & Social Service \\
\hline \multirow[t]{7}{*}{ Theory } & & $\begin{array}{l}\text { English } \\
\quad \text { Conversation }\end{array}$ & E-Learning Selection & $\begin{array}{l}\text { E-Learning } \\
\text { Selection }\end{array}$ \\
\hline & & PLC Practice & $\begin{array}{l}\text { Electrical Instrument } \\
\text { Practice }\end{array}$ & $\begin{array}{l}\text { Vocational Ethics } \\
\text { and } \\
\text { Relationship }\end{array}$ \\
\hline & & $\begin{array}{l}\text { Electrical } \\
\text { Instrument }\end{array}$ & $\begin{array}{l}\text { Electricity and Fire- } \\
\text { fighting Installation }\end{array}$ & $\begin{array}{l}\text { Electric Power and } \\
\text { Electricity } \\
\text { Practice }\end{array}$ \\
\hline & & $\begin{array}{l}\text { Electric Power } \\
\text { System }\end{array}$ & $\begin{array}{l}\text { Electricity Control } \\
\text { Practice }\end{array}$ & $\begin{array}{l}\text { Electricity Applied } \\
\text { Practice }\end{array}$ \\
\hline & & $\begin{array}{l}\text { Microprocessor } \\
\text { Visual } \\
\text { Programming }\end{array}$ & $\begin{array}{l}\text { Electric Installation } \\
\text { Quotation }\end{array}$ & $\begin{array}{l}\text { LAB NEW Applied } \\
\text { Practice }\end{array}$ \\
\hline & & Sequence Practice & $\begin{array}{l}\text { Computer Applied } \\
\text { Practice }\end{array}$ & $\begin{array}{l}\text { Electric Motor } \\
\text { Applied Practice }\end{array}$ \\
\hline & & & $\begin{array}{l}\text { Electricity Application } \\
\text { PLC Applied Practice }\end{array}$ & OJT \\
\hline
\end{tabular}

Source: Kim (2010) 
Table 16.14 Main subject status on the department of renewable energy electricity in Yeungjin College

\begin{tabular}{|c|c|}
\hline $\begin{array}{l}\text { Basic practice on } \\
\text { renewable energy }\end{array}$ & $\begin{array}{l}\text { Introduction to renewable energy-related technology } \\
\text { The understanding of photovoltaic power generation through } \\
\text { photovoltaic system }\end{array}$ \\
\hline Solar cell & $\begin{array}{l}\text { The understanding of types and characteristics of solar cells } \\
\text { The understanding of solar cell manufacturing process }\end{array}$ \\
\hline $\begin{array}{l}\text { Applied practice on } \\
\text { renewable energy }\end{array}$ & $\begin{array}{l}\text { Introduction to renewable energy technology-related intensive theory } \\
\text { as renewable energy basic practice } \\
\text { The understanding of wind power generation and fuel cell practice } \\
\text { apparatus }\end{array}$ \\
\hline $\begin{array}{l}\text { Photovoltaic power } \\
\text { generation system }\end{array}$ & $\begin{array}{l}\text { Principle of photovoltaic power generation, construction preparation } \\
\text { of photovoltaic power generation system } \\
\text { The understanding of process on planning, installation, and testing } \\
\text { Market trend and prospect of photovoltaic power generation }\end{array}$ \\
\hline LED display lighting & $\begin{array}{l}\text { The understanding of characteristics on LED display lighting } \\
\text { Design technology on LED display lighting power supply } \\
\text { Market trend and prospect of LED display lighting }\end{array}$ \\
\hline
\end{tabular}

Source: Kim (2010)

Table 16.15 Contents of practical training courses on green energy electricity and electric work in Yeungjin College

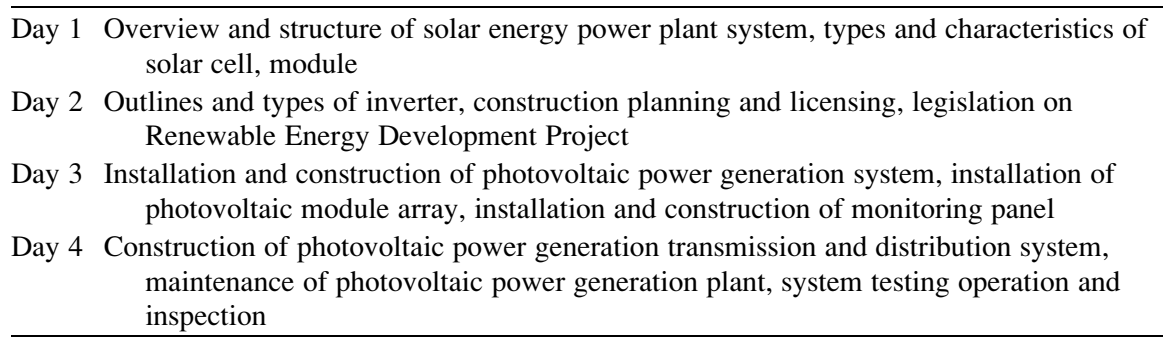

with green growth and developed new personnel who will lead the green industry. This section focuses on the discussion of the strategies and changes on vocational education and training for developing green talents who would support the green growth of the Republic of Korea. However, as the industrialization of the Republic of Korea's economy was developed under the backdrop of nation-led economic development policies and national human resources development policies, the characteristics of the Republic of Korea's vocational education and training are first introduced to provide basic understanding on such attributes. This is because it would be hard to understand the Republic of Korea's vocational training program newly established in accordance with the nation's green growth policies, if the human resources development policies, which greatly helped the Republic of Korea's unprecedented fast economic development, are not taken into consideration.

The green job vocational education and training development expansion policy tasks, set by the Green Growth Committee, are presented as follows: green job 
employment support and manpower training plans. Mainly, policy tasks are presently aimed at training green manpower on a pan-government basis and promoting green growth by effectively reorganizing the manpower through improving the condition necessary for labor mobility.

\section{Vocational Education and Training Policy Overview Under the Green Policy}

First, to foster technology functional manpower to promote the green industry as the new growth engine, the government enhances the training of high-quality technological manpower and technical manpower of core green industries, where demand has been on the increase with the industrialization of core green technologies. It designates or creates manpower training centers and pushes forward raising technical manpower through cooperation with sectoral councils in the green industry area. In addition, as a project is underway to reorganize unemployment training as green friendly so that those leaving non-green industry can swiftly move to green employment, it heightens the possibility of those unemployed people in traditional manufacturing sectors transferring to green-related industry areas.

Second, to make the existing industries green, the government established a green employee transfer training system with the advance of greening of major existing industries such as automobile, steelmaking, shipbuilding, and pushed forward with the policies that support education and training expenses when providing green industry-related education and training. In addition, to improve the effectiveness of employee reeducation training, support has been offered for the expansion of green factory innovation by forming an HRD consortium and supporting green factory innovation.

Third, to support the training of core personnel who can increase the green industry competitiveness of SMEs, detailed supporting measures have been developed and propelled that would support SMEs' core personnel with education expenses and wage subsidy (minimum wage 100\%) in green technology, management innovation. The measures offer (annually 1,000 persons) SMEs' high-quality research personnel employment support in the green industry area such as green technology development. Furthermore, to train beginning to intermediate-level technicians responding to the green demand for regions and industries such as the formation of green clusters based on regional characteristics, green technology manpower has been raised in Korea Polytechnics ( 6 areas, 38 campuses), the regional base public training organization increasing from 300 in 2008 to 1,800 in 2012.

Fourth, while initiating green qualification items to establish the national technology qualifications system of the green industry and leading the training of green industry technology manpower, the government reorganizes the existing national technology qualifications to be green friendly, enhances the quality control of the green qualifications, and expands the opportunities to acquire green qualifications, consequently making the overall national technology system play an important role in training green talents. 
Finally, by continuously increasing the proportion of investment in basic and original green technology, the government expands green technology-related researches and promotes investment in fusion green technologies such as IT and NT, which will lead future green growth. In addition, by paying attention to the need to secure the green growth engines by training core green technology talents, the government supports engineering colleges (graduate schools) in training greenrelated specialized graduate schools, continues to support basic research support programs in the science engineering and fusion basis research fields, and enhances related education and research capabilities. Through the activation of developed basic technologies, the government simultaneously enhances the cooperation between academic research organizations and through these efforts creates base technologies and expands the training of specialized manpower.

The Republic of Korea must be consistent in carrying out policies and projects by conducting dimensional and integrated diagnoses on the scale of further green energy industry, the scope of further enlargement, and manpower supply and demand in both qualitative and quantitative terms. It is necessary for policies for green energy to be pushed ahead with a strategic road map revolving around practical administrative and financial supports as well as the modification of various laws and regulations related to training manpower for the green energy sector.

In the cases of green jobs, jobs have been created as the Republic of Korea has set green growth at the forefront of the new changes and has pushed forward intentionally due to various international economic and environmental reasons. However, it is important to recognize that these jobs are not created by a natural link between education and labor market, but rather as a result of efforts to achieve the government's policies. Various vocational training programs for manpower development are necessary to support the government's green growth policies and researches.

\section{Republic of Korea's Experiences Helpful to Less-Advanced Countries in Asia}

First, less-advanced countries should establish a system to promote green skill training. They should establish a green skills training system focusing on companies and their employees based on the demand for a market-friendly skill development system and customized skill development systems.

Second, those governments should implement skills training policies that can support various training activities such as informal training, formal training, and blended learning for green growth.

Third, the direction of support needs to shift toward one that can lead and induce green growth by promoting participation in skills training of a customized support system.

Fourth, to promote the programs and action plans for skills training described above, the Republic of Korea can expand its multilateral programs and be ready to cofinance all the support activities in collaboration with other international organizations for more effective implementation. 
Fifth, the Republic of Korea believes that one of its best possible contributions to less-advanced countries would be cooperating with them to promote skill development and make progress toward green growth. In order to promote green growth strategies for improvement of green skills, the Republic of Korea can provide efficient policy directions to support them in achieving green skills training for green growth.

Open Access This chapter is distributed under the terms of the Creative Commons Attribution Non-commercial License which permits any non-commercial use, distribution, and reproduction in any medium, provided the original author(s) and source are credited.

\section{References}

ABD. (2011). Skills for inclusive and sustainable growth $n$ developing Asia-Pacific: An international consultative form. Unpublished Paper.

European Center for the Development of Vocational Training. (2010). Skills for green jobs: Country report Germany. Luxembourg: CEDEFOP.

ILO. (2010). Skills for green jobs in the United States. Geneva: ILO.

Inter-ministerial Committee. (2009). Unpublished report. (in Korean)

Kim, D. H. (2010). Green growth and vocational education and training development policy $3 r d$ forum materials. Korea Research Institute for Vocational Education \& Training. (in Korean)

Ko, H. W (2010). Green technology related occupational education and training reorganization, In Y. S. Na \& others (Eds.), Green growth and skills development policies. Korea Research Institute for Vocational Education \& Training (Korean). (in Korean)

Korea Eximbank. (2012). Education and skills for inclusive growth and green jobs: [Republic of] Korea's experiences on education and skills for green jobs. KSP-ADB Joint Consulting Program.

Lee, N. C. (2010). Green growth and labor market in [the Republic of] Korea. The Business Review, Cambridge, 15(1), 104-112.

Lee, N. C., et al. (2010a). Fundamental research of green jobs related to water resources. Korea Research Institute for Vocational Education \& Training. (in Korean)

Lee, N. C. et al. (2010b). Utilization and green jobs of water, wind and solar photovoltaic resources. Korea Research Institute for Vocational Education \& Training. (in Korean)

Lee, N. C. et al. (2012). Analysis on employment creation of renewable energy sector. Korea Research Institute for Vocational Education \& Training. (in Korean)

Ministry of Environment. (2010). National Solar Jobs Census 2010. (in Korean).

OECD. (2010). Green jobs and skills: The local labour market implications of addressing climate change. Paris: OECD.

OECD. (2011). Towards green growth. Paris: OECD.

Presidential Committee on Green Growth. (2010). Road to our future green growth. Seoul: Presidential Committee on Green Growth. (in Korean)

Ra, Y. S., et al. (2010). Green growth \& skills development policy. Korea Research Institute for Vocational Education \& Training (in Korean).

State Council of Ministry of Strategy and Finance, Ministry of Education, Science and Technology, Ministry of Culture, Sports and Tourism, Ministry of Food, Agriculture, Forestry and Fisheries, Ministry of Knowledge Economy, Ministry of Environment, Ministry of Land, Transport and Maritime Affairs, Prime Minister's Office, National Emergency Management Agency, \& Korea Forest Service. (2009). The promotion plan of green new deal project for job creation (in Korean).

UNEP. (2008). Green jobs: Towards decent work in a sustainable, low-carbon world. France, Germany, The Netherlands, Spain, The United Kingdom and The United States. 